\title{
GEOPHYSICAL INVESTIGATIONS OF THE EDWARDS-TRINITY AQUIFER SYSTEM AT MULTIPLE SCALES: INTERPRETING AIRBORNE AND DIRECT-CURRENT RESISTIVITY IN KARST
}

\author{
Marcus O. Gary \\ Edwards Aquifer Authority, 900 E. Quincy,San Antonio,TX 78215, USA, mgary@edwardsaquifer.org \\ Dale F. Rucker \\ HydroGEOPHYSICS, Inc., 2302 N. Forbes Blvd., Tuscon, AZ 85745, USA, druck8240@gmail.com
}

\section{Bruce D. Smith, David V. Smith}

United States Geological Survey, Crustal Geophysics and Geochemistry Science Center, P.O. Box 25046, MS973, Denver Federal Center, Denver, CO 80225,USA, bsmith@usgs.gov,dvsmith@usgs.gov

\section{Kevin Befus}

The University of Texas at Austin, Department of Geological Sciences, 1 University Station C9000, Austin, TX 78712,USA, kevin.befus@mail.utexas.edu

\begin{abstract}
Electrical and electromagnetic geophysical characterization is a proven tool for delineating obscured subterranean karstic features, such as caves, sinkholes, and solution enlarged fissures. Geophysical characterizations allow a wide range of deployment scales; airborne methods can accommodate a regional view on the order of kilometers, and ground-based methods can follow up with focused data on the order of meters. A helicopter frequency domain electro-magnetic (HFDEM) survey and ground-based direct-current electrical resistivity imaging (DC-ERI) geophysical studies at the Camp Bullis Military Training Site (Camp Bullis) in central Texas have been used to characterize permeability properties of the Edwards and Trinity Aquifers in the area. Results of three separate investigations identified zones of high density karst features and characterized specific karstic voids, including caves. In 2003, the USGS completed an HFDEM survey of Camp Bullis and nearby areas to map and image subsurface features related to the groundwater resources. The survey refined locations of mapped and previously unmapped faults and characterized the heterogeneity of the subsurface electrical signature. Karst mapping at Camp Bullis identified over 1500 features, and high density zones of features correspond with areas of high resistivity from the HEM data. DC-ERI surveys at several locations were used to infer and characterize known and hypothesized karst features. Site 8 suggests an inferred fault and
\end{abstract}

dissolution feature. Two other sites were surveyed near major caves that directly recharge the Trinity Aquifer (indirectly to Edwards Aquifer) along Cibolo Creek. Integration of multi-scale geophysical datasets could be used to augment aquifer-wide recharge characterization and quantification.

\section{Introduction}

The Edwards and Trinity Aquifers are critical water resources, supplying high-quality potable water to over two million people in the greater Austin-San Antonio region of central Texas, USA. These carbonate aquifers are structurally juxtaposed by extensive Miocene tectonic deformation associated with the Balcones fault zone, where the younger Edwards Group has been downthrown relative to the older Trinity Group. These karstic aquifers are managed separately by regional water regulatory entities, and have been historically treated as independent systems, both scientifically and from a water policy standpoint.

Three separate electrical geophysical investigations at Camp Bullis Military Training Site (Camp Bullis) (Figure 1) were performed to characterize the hydrogeologic properties of this $113 \mathrm{~km}^{2}(28,000$ acre $)$ area that includes both Edwards and Trinity Group outcrops. In 2003, the U.S. Geological Survey completed a helicopter frequency domain electro-magnetic (HFDEM) survey of Camp Bullis and nearby areas to map and image 


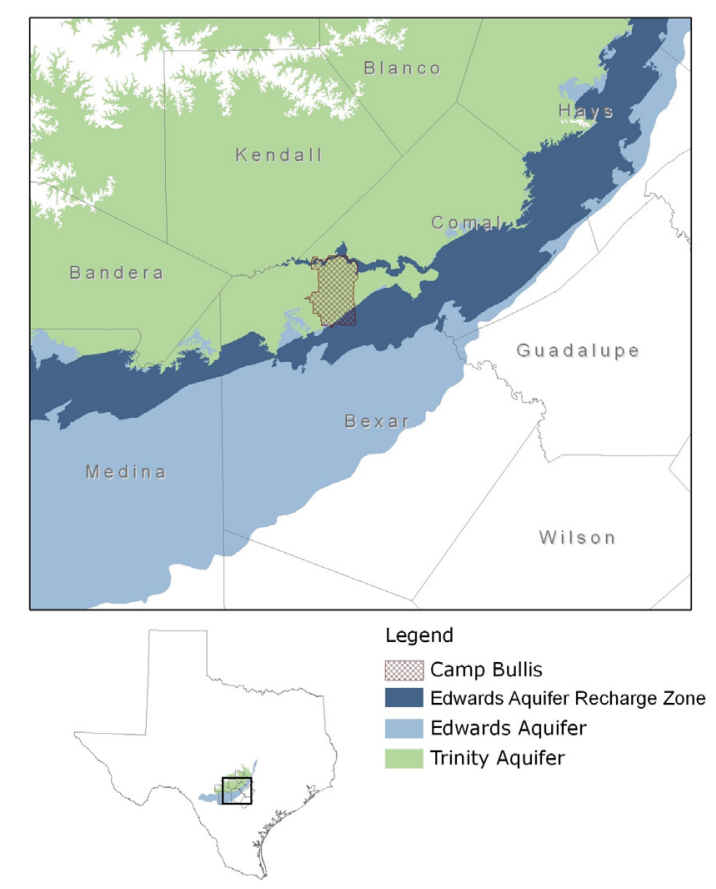

Figure 1. Location of Camp Bullis lies within the Edwards and Trinity aquifers (Zara, 2011).

subsurface features related to groundwater resources. DC-ERI surveys at several locations have been used to infer and characterize known and hypothesized karst features and structural features. One of these sites, located near a heavily investigated remediation area (Site 8; Figure 4) possibly indicates an inferred fault and dissolution feature. Two other sites were surveyed near major caves that directly recharge the aquifers along Cibolo Creek on the north side of Camp Bullis with mixed geophysical results. The HFDEM data provide a regional-scale survey of Camp Bullis and the surrounding area and are complemented with two site specific DC-ERI surveys that provide more details of localized electrical resistivity properties related to dissolution features.

\section{Hydrogeologic Setting}

The hydrogeologic setting of Camp Bullis has been documented in numerous reports related to the Edwards and Trinity Aquifers, both formed in Cretaceous limestones. Two publications in particular focused directly on the surface geology (Clark, 2003) and structure of the bedrock (Ferrill et al., 2003). The Edwards Group (Kainer Formation) covers the southern third of Camp Bullis. The USGS published a lithologic description of the Edwards in Bexar County
(Stein and Ozuna, 1995). The Glen Rose Limestone covers the northern two-thirds and most of the subsurface of Camp Bullis. It is divided into two members. The upper member has been divided into five hydrogeologic intervals, previously designated A through E (Clark, 2003), but the intervals were formalized with names by Clark et al. (2009). Figure 2 shows a three dimensional block diagram of Camp Bullis (Zara, 2011).

The cavernous member (interval A) is formed by alternating and interfingering mudstone, wackestone and packstone and is well karstified. It overlies the Camp Bullis member (interval B), which is lithologically similar to the cavernous member, but has less karst development and lower permeability. The upper evaporite member (interval C) is a thin layer of highly soluble carbonates and evaporites, characterized by breccia porosity, boxwork permeability and collapse structures. The fossiliferous member (interval D) has low porosity and permeability, with the exception of a caprinid biostrome near the top of the interval, which is well karstified. This biostrome is thickest in the center of Camp Bullis, and thins to the north. The lower evaporite member (interval E) is quite similar to the upper evaporate member (interval C), with mostly dissolved evaporites diverting groundwater horizontally. The lower member of the Glen Rose Limestone is composed primarily of massive, fossiliferous limestone and is well karstified with significant recharge features (fractures, faults, and caves that rapidly transmit surface water to the aquifer) along Cibolo Creek.

The area in and around Camp Bullis has been extensively karstified, fractured, and faulted, both in the Kainer Formation (Edwards Group) and Glen Rose Formation (Trinity Group). Detailed surveys were conducted over many years, documenting over 1500 karst features (Zara, 2011). Karst feature density was estimated using karst feature locations and the weighted karst significance values (0-720), as quantified by Zara and Veni (2010). Features' significance numbers were determined by giving numerical values to each karst feature, using hydrogeological characteristics proportional to potential recharge. Results are shown in Figure 3, with darker areas indicating higher karst density and significance. These data are correlated with results of geophysical studies. 


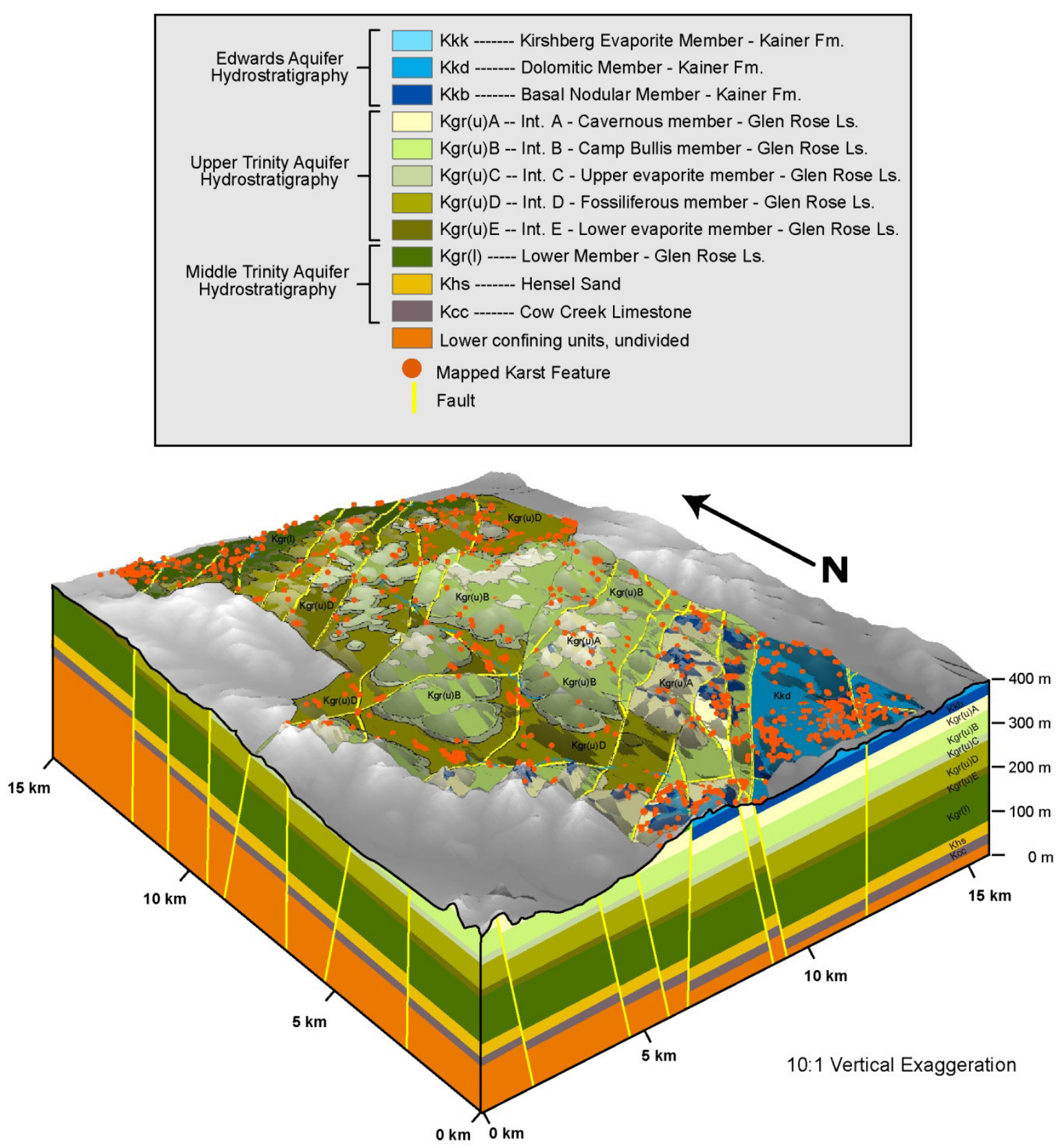

Figure 2. Block Model of Camp Bullis based on Clark (2003) and Ferrill et al. (2003). Mapped karst features are shown as orange points. Figure modified from Zara, 2011.

\section{Geophysical Investigations}

Three independent geophysical investigations are shown here to display different scales of data collected at Camp Bullis. Locations of all the studies are shown in Figure 4, including the HFDEM surveys, the Site 8 DC-ERI remediation survey, and two DC-ERI surveys along Cibolo Creek to the north (Jabbas Giant Sink and Bullis Hole).

\section{Airborne Electromagnetic Survey}

A HFDEM survey was flown over a portion of northern Bexar County covering the Edwards Aquifer Recharge Zone and the Trinity Aquifer at Camp Bullis, Camp Stanley Storage Activity (adjacent to Camp Bullis on the west), and part of Cibolo Creek east of Camp Bullis (Figure 4). The HFDEM survey used the RESOLVE ${ }^{\odot}$ system flown by Fugro Airborne Surveys, which uses 


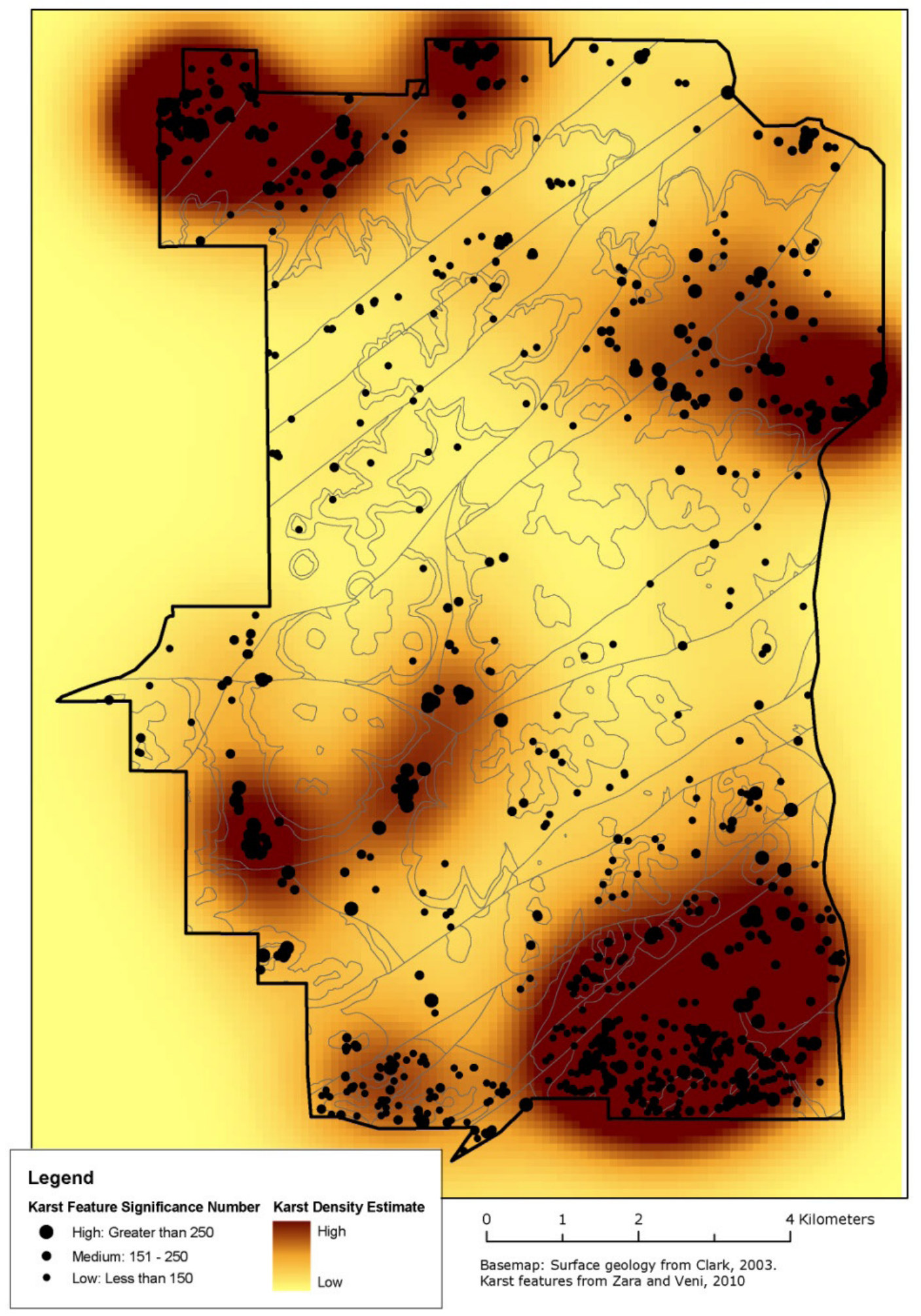

Figure 3. Karst feature density map of Camp Bullis showing the spatial distribution and significance number of karst features (Zara, 2017). 


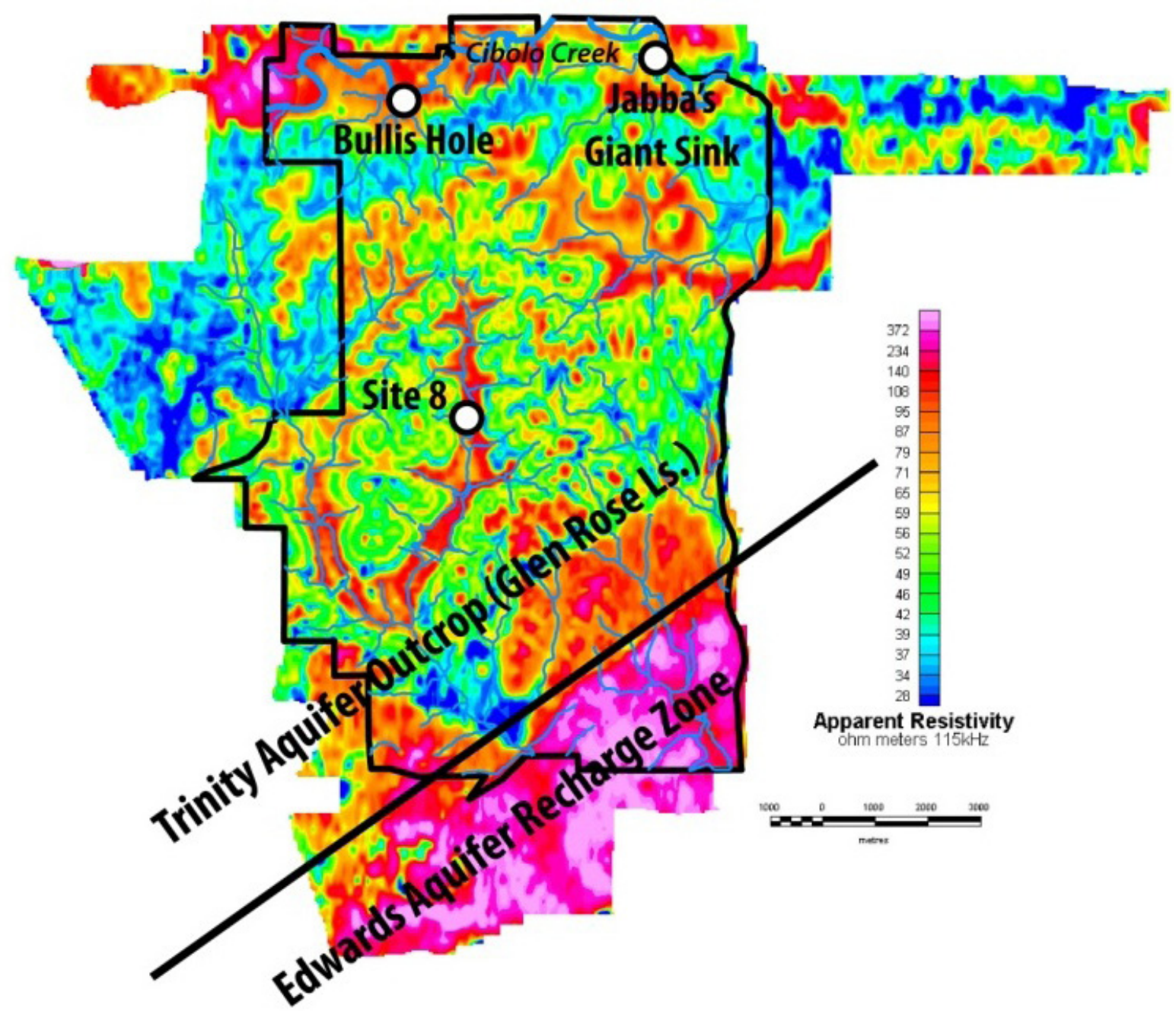

Figure 4. HFDEM survey data at $115 \mathrm{kHz}$ frequency from Camp Bullis. DC-ERI sites are shown as white circles. The Edwards-Trinity contrast is clearly shown in the HFDEM data (Smith et al, 2005) The water table is 30+ meters below the land surface throughout Camp Bullis, thus these resistivity values reflect the vadose zone.

five horizontalcoplanar coils and one vertical coaxial coil for electro-magnetic field measurements. The six frequencies ranged from $400 \mathrm{~Hz}$ to $115,000 \mathrm{~Hz}$. Details of the survey specification and digital data aredescribed by Smith et al. (2005). The survey was flown with east-west flight lines and a nominal line spacing of $200 \mathrm{~m}$ with a sensor elevation of $30 \mathrm{~m}$ except as required for safety considerations and FAA regulations. In-fill lines were flown in the central part of the survey area to yield an effective flight line spacing of $100 \mathrm{~m}$. The measured electromagnetic fields were converted to apparent resistivity by the contractor for each frequency. The depth of penetration increases with decreasing frequency and with increasing resistivity. The shallowest depth of penetration is for $115,000 \mathrm{~Hz}$ which averaged 7 meters for all of the survey. The apparent resistivity is shown in Figure 4.

The survey refined locations of mapped, located previously unmapped faults, and characterized the heterogeneity of the subsurface electrical signature. In general, the massive limestones of the Edwards Recharge Zone at the southern end of the survey are shown as an area of very high apparent resistivity (100s of $\Omega-\mathrm{m}$ in the HFDEM survey). The sharp NE trending boundary between the high resistivity on the south and more moderate apparent resistivity to the north reflects a normal fault boundary between the Edwards and Trinity Aquifers. The Trinity Aquifer is characterized 
by alternating mudstones, siltstones (low resisitivities; cooler colors in Figure 4), and limestones (warmer colors) which give the aquifer a variable signature. In general the upper part of the Trinity Aquifer is composed of thin discrete limestone and siltstone layers that give the variegated color pattern in Figure 4. The middle Trinity is composed of more massive reefal structures within mudstone units.

The trends in the apparent resistivity map correlate to and augment the mapped geology. The HFDEM map shows greater detail in the lithologic changes than indicated in geologic maps such as the thin limestone units and more detail in structural trends. There is also a strong correlation of the occurrence of karst features (Figure 3) with the HFDEM map, suggesting that the geophysical data may also reflect values of high resistivity that would be significant if large volumes of air-filled voids (very high resistivity) exist in the subsurface.

\section{Site 8 DC-ERI}

A surface-based electrical resistivity survey was conducted south of the Site 8 Landfill to map the structure of the top $50 \mathrm{~m}$ of the exposed Glen Rose limestone. The landfill is located approximately in the center of Camp Bullis, to the west of Lewis Creek (Figure 5A). The purpose of the resistivity survey was to gain a better understanding of potential karst features that would help explain contaminant transport through the underlying aquifer. Contaminants were detected in a number of wells down gradient of the site, just south of the area shown in Figure 5.

The resistivity data were acquired along 16 transects spaced approximately $6 \mathrm{~m}$ apart. The pole-pole array was used for acquisition, with remote electrodes placed at least $700 \mathrm{~m}$ away. Transects were about $95 \mathrm{~m}$ long with $3 \mathrm{~m}$ electrode spacing and data were collected with a SuperSting R8. The pole-pole array is known to provide rapid acquisition with high signal to noise ratio and deep imaging. However, the array also has the lowest resolution and therefore not optimal for locating small scale features that would provide the best insight into the range of sinkhole sizes. To accommodate a higher resolution, the pole-pole data were converted to an optimized four-pole array that included external dipoles (similar to the dipole-dipole array), internal dipoles (Schlumberger array), and overlapping dipoles according to the procedure outlined in Loke et al. (2010). The conversion of two-pole to four-pole data was conducted through superposition (Rucker, 2012).

Although the data were collected along 2D transects, the spacing between lines allowed the domain to be modeled in three dimensions, to a depth of $45 \mathrm{~m}$ below ground surface. RES3DINVx64 was used to inverse model the data and was opted for additional diagonal smoothing to reduce striping inherent in modeling volumes comprised of individual transects. The results of the resistivity distribution are shown in Figure 5B as an overhead view of two resistivity isopleths: $250 \Omega-\mathrm{m} \mathrm{s}$ a transparent lighter blue and $400 \Omega-\mathrm{m}$ as a darker opaque blue (which can be observed through the lighter transparent blue in the northwestern portion of the site).

Values lower than $250 \Omega$-m have been removed making those areas devoid of color, i.e., the lowest values have been blanked. Based on the vertical distribution of resistivity, the figure highlights the resistivity values in the upper $11 \mathrm{~m}$ of the domain. Below $11 \mathrm{~m}$, the resistivity values are less than $250 \Omega-\mathrm{m}$, likely due to the influence of increased saturation.

The results show that there is an overall trend of high resistivity features that align along an approximate N22E strike to the northeast. A clear banding of the highest values can be observed through the center of the site, which likely represents more competent limestone. The low resistivity material that has been removed from the image is hypothesized to be soil-filled buried sinkholes with higher clayey material and moisture content. Unfortunately, wells drilled in the immediate vicinity of the study did not uncover evidence of sinkholes, as they were placed prior to resistivity acquisition. The sinkholes appear to also align at N22E or perpendicular at N58W. Arrows have been provided to highlight these directions. The spatial density of low resistivity material increases in size and number towards the east (closer to Lewis Creek). Given this information, two possible scenarios of contaminant transport emerge. Either the sinkholes provide a means of recharge from landfill runoff, or possibly the underlying landfill liner (if one existed) integrity has been breached through further sinkhole development.

\section{Cibolo Creek Karst Features}

Two field DC-ERI surveys focused on imaging known air-filled karst features located within the floodplain of 


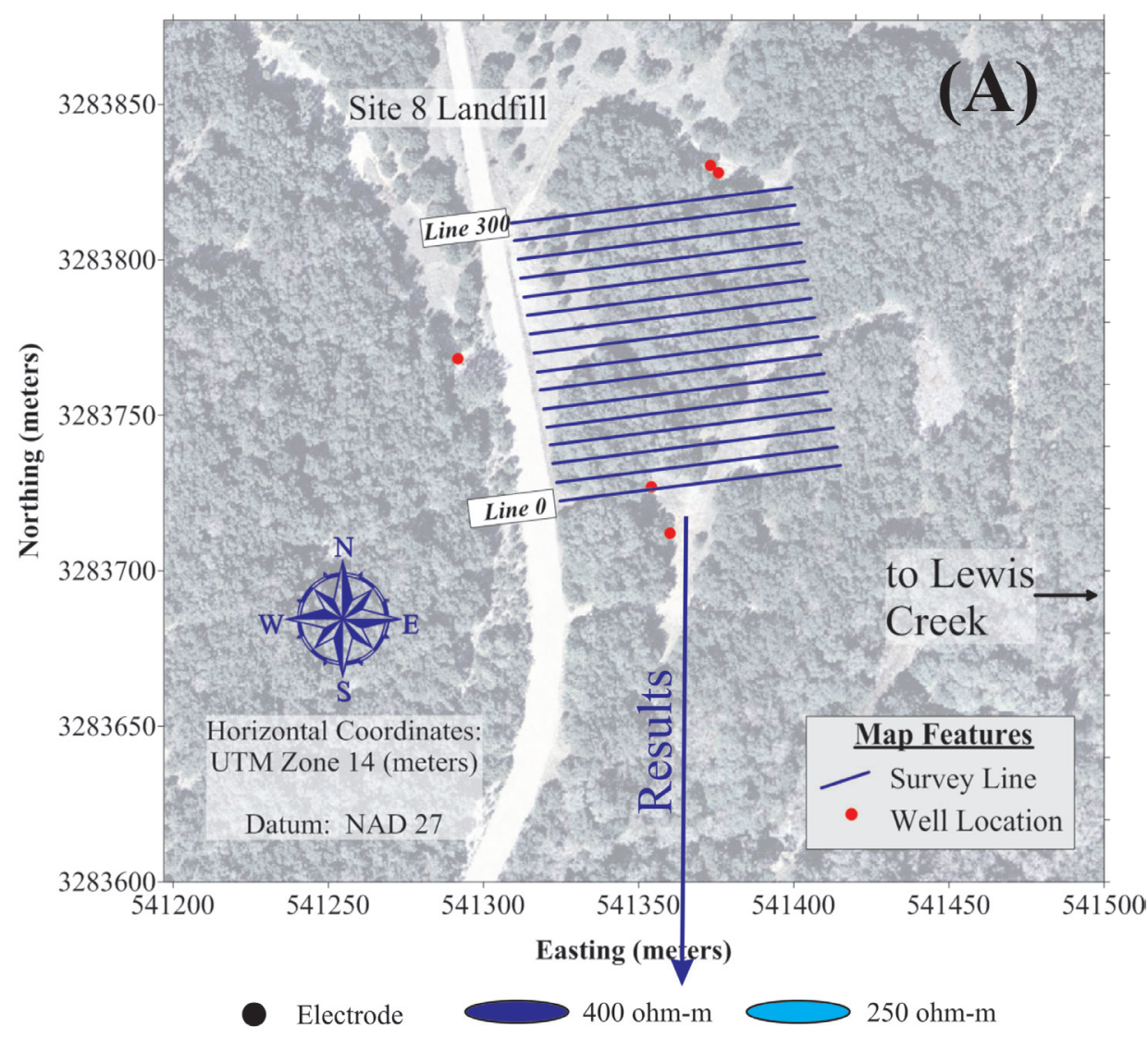

Figure 5. (A) Study area of surface resistivity south of the Site 8 Landfill showing the survey lines. (B) Overhead view of three dimensional resistivity showing two isopleths: 250 (light blue) and 400 $\Omega$-m (dark blue). Values less than $250 \Omega-m$ were removed to highlight patterns of potential sinkholes filled with soil. The medium blue is from the combined effect of both blues. Electrodes are black dots.

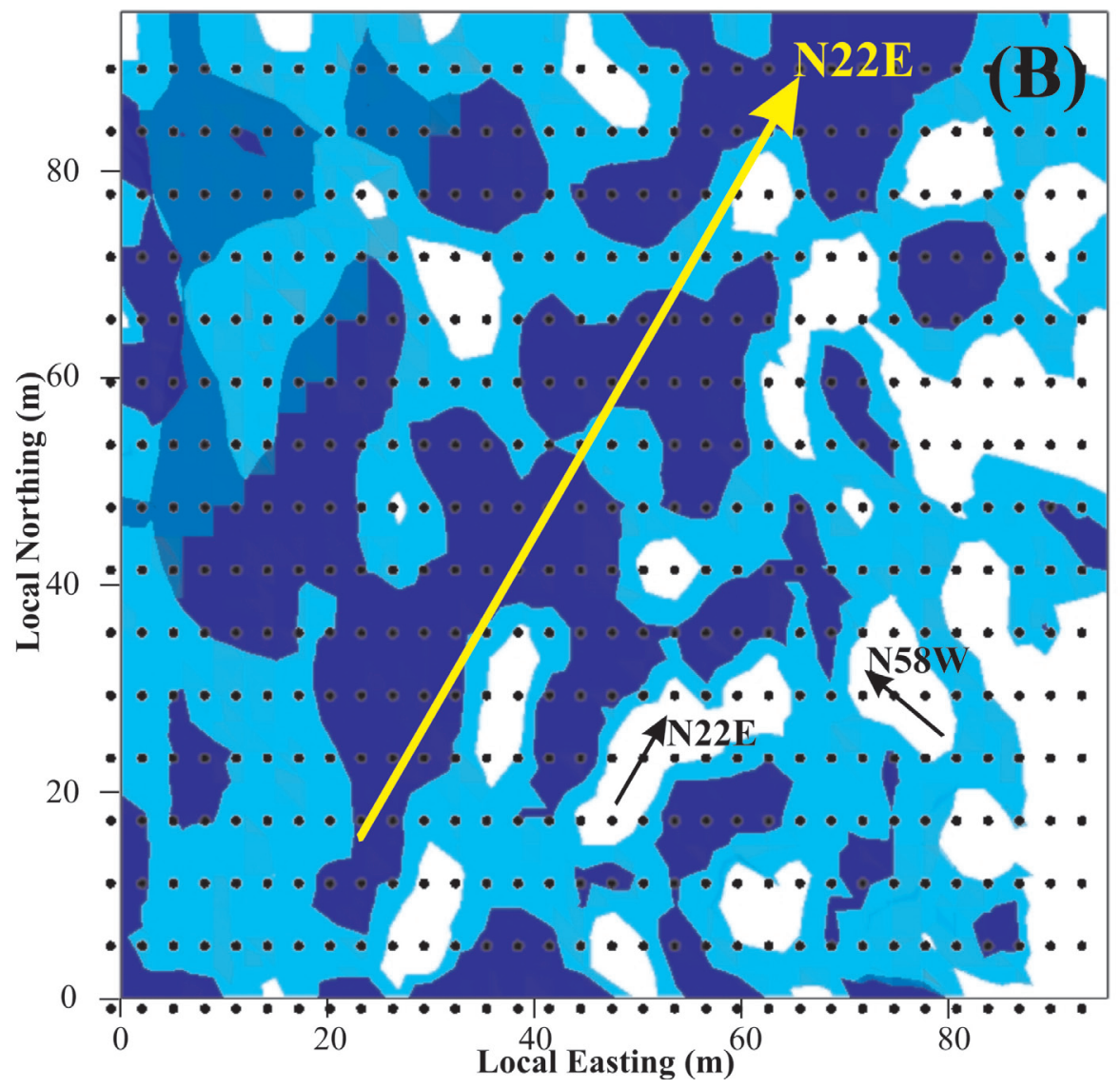


Cibolo Creek at the northern border of Camp Bullis. The two target features were Bullis Hole and Jabba's Giant Sink. Both have cave entrances located on the creek bluff and are mapped to extend below Cibolo Creek (Zara and Veni, 2010).

Two creek-parallel, cave-perpendicular 2D ER lines were recorded at Bullis Hole (Figure 6). The first line ran across sinkholes associated with the cave entrance, and the second line was $30 \mathrm{~m}$ northeast of the first line, beyond where Bullis Hole was mapped (Figure 7). At Jabba's Giant Sink (Figure 8), two nearly perpendicular 2D ER lines crossed over the cave location (Figure 9). Electrode spacing ranged from 1.5 to $5 \mathrm{~m}$, depending on the depth required for imaging the karst features and the available space. Dipole-dipole and Schlumberger datasets were collected and merged prior to inversion for each line. Line topography was recorded with a total station and included in the inversion. The merged datasets were inverted in RES2DINVx64 with a robust model constraint.

The ER line running over the Bullis Hole sinkhole captured the subsurface expression of the cave (Figure 7). The main collapse area was noted at location 72-73 $\mathrm{m}$ along Line 1 and coincides with a small high resistivity ( $>250 \Omega-\mathrm{m})$ anomaly within $1 \mathrm{~m}$ of the surface. A more notable high resistivity feature was imaged adjacent to the sinkhole (66$69 \mathrm{~m}$ ) that extended to $5 \mathrm{~m}$ depth, which was interpreted to represent the shallow passage of Bullis Hole just offset from the ER line where both the depth $(\sim 2 \mathrm{~m})$ and size of the cavity agree between the ER and cave map. Uncertainty in the imaged feature's dimensions result from the threedimensionality of electrical properties in the subsurface that are modeled in 2D, and the ER inversion process inherently smooths discrete and abrupt ER features and boundaries (Day-Lewis et al. 2005). The Line 2 inversions did not resolve any apparent karst features.

Jabba's Giant Sink extends under Cibolo Creek and was imaged well by the ER surveys (Figure 9). In Line 1, a highly resistive feature $(>300 \Omega-\mathrm{m})$ was imaged at the cavern depth $(10 \mathrm{~m})$ at the correct position along the line $(\sim 75 \mathrm{~m})$. The extension of the high ER values at the same depth suggest some lateral extension (54-99 $\mathrm{m}$ ) of voids in the subsurface, as near equal horizontal and vertical smoothing (averaging) was used during the inversion. Line 2 intersected Line 1 near the projection

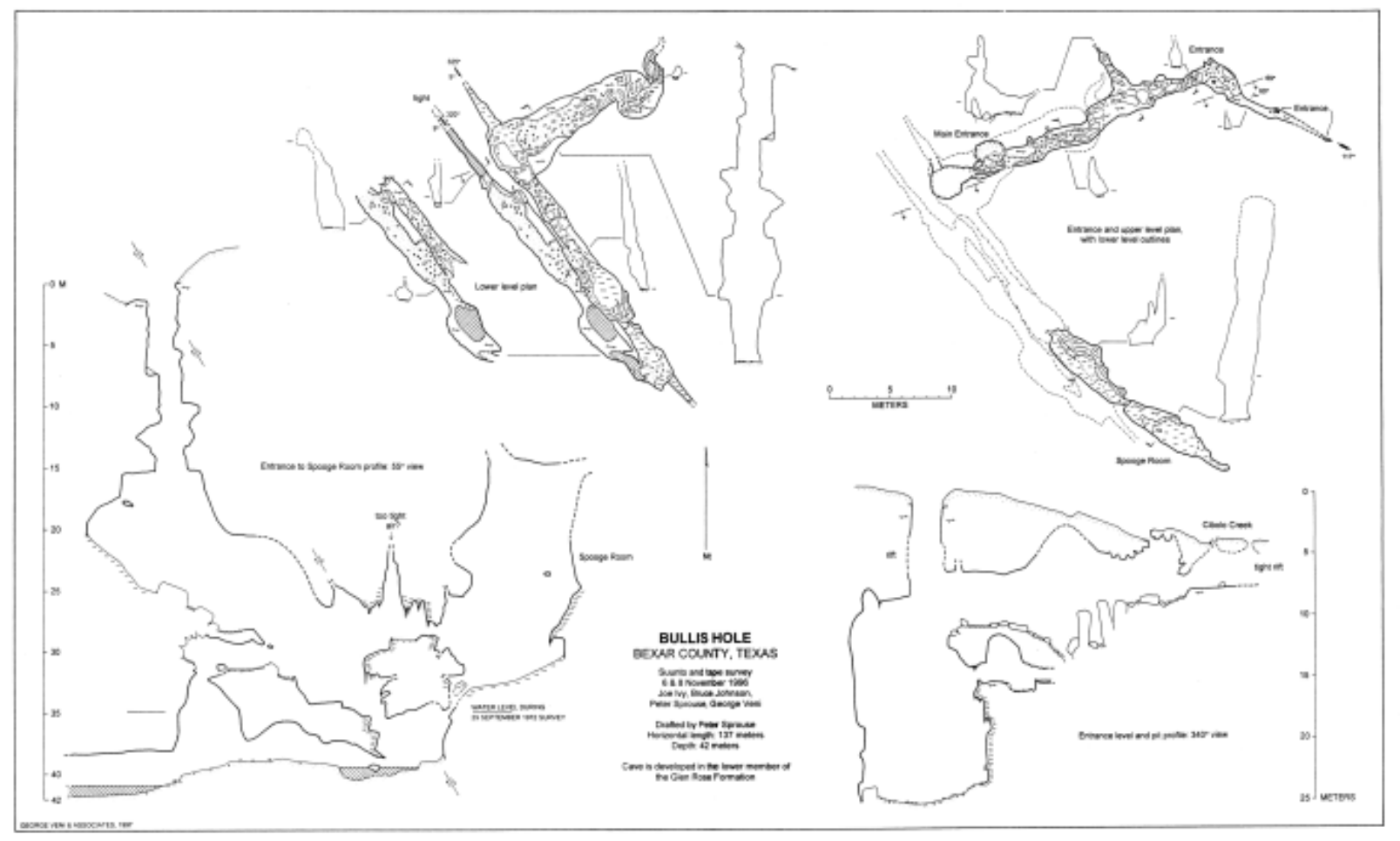

Figure 6. Cave map shows Bullis Hole cave, which is located on the right bank (south) of Cibolo Creek. This cave extends below the creek bed (Zara and Veni, 2010). 


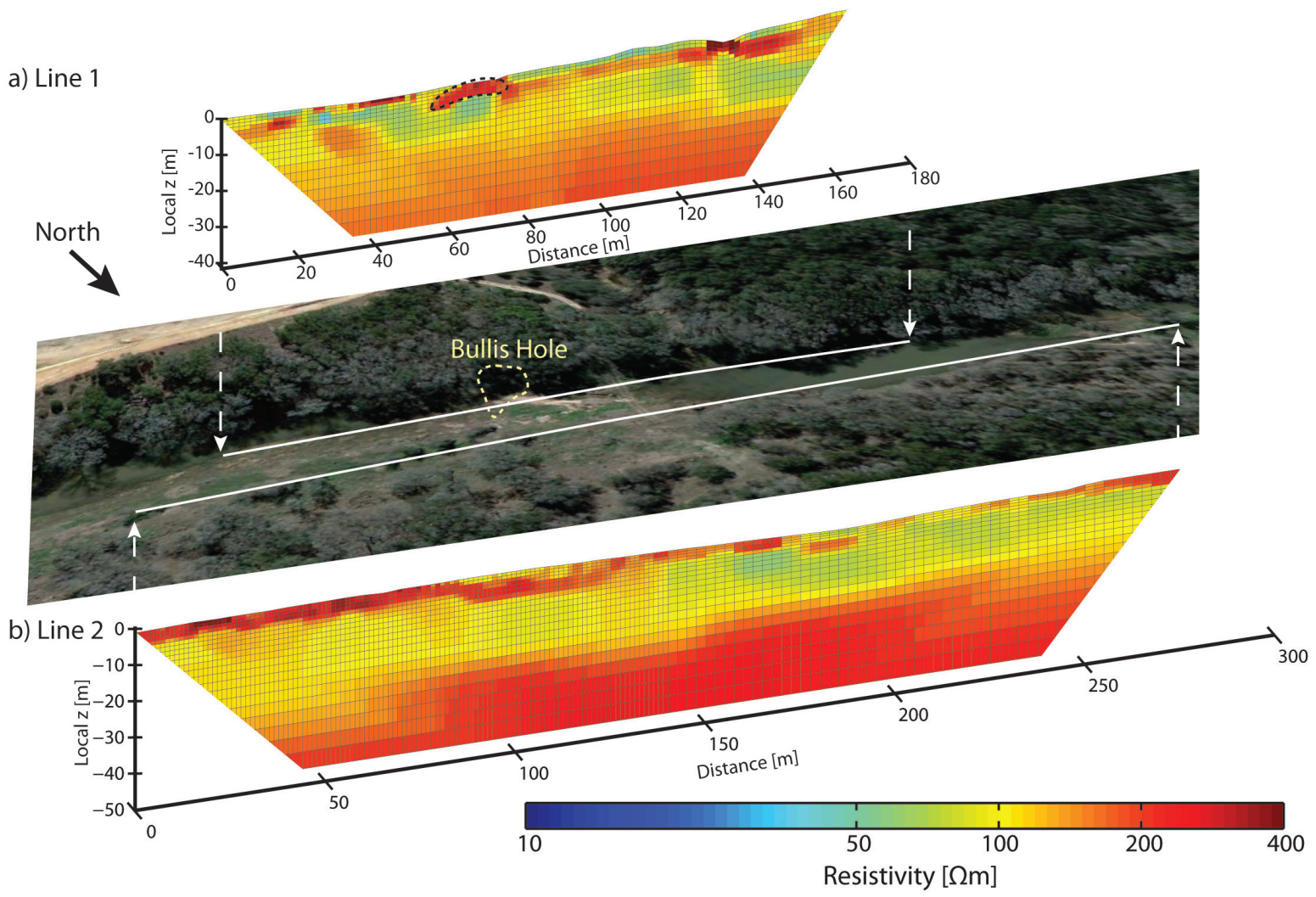

Figure 7. ER results at Bullis Hole cave. Line 1 imaged a high ER area where the cave crossed the line ( $\sim 70$ m). The second line did not reveal any new potential karst voids.

of Jabba's Giant Sink, and high resistivity values (> $200 \Omega-\mathrm{m})$ between $33-42 \mathrm{~m}$ on Line 2 were centered on the expected cave depth $(\sim 10-12 \mathrm{~m})$. A thin resistive anomaly further down the line $(50-52 \mathrm{~m})$ at $5 \mathrm{~m}$ depth may represent a small cavity.

\section{Discussion}

In this paper, we evaluated three geophysical case studies performed at Camp Bullis. They were each conducted independently from one another with different specific objectives and a range of scales. The HFDEM survey utilized regional-scale methodology to capture the subsurface electrical properties of the geology beneath Camp Bullis and surrounding areas. The Site 8 investigation imaged the geophysical signature near a contaminant remediation site, characterizing variable zones of resistivity, relating to possible locations of karstic features. DC-ERI surveys along Cibolo Creek directly targeted known, mapped caves below the creek bed, and these caves have been observed to discretely recharge into the aquifer. A next step would be to link these disparate studies with other known hydrogeologic, hydrologic, and geomorphic data to improve the understanding of recharge heterogeneity across the aquifer system. To accomplish this at Camp Bullis, we would utilize HFDEM data as the common data set.

Comparison of the HFDEM data (Figure 4) with the mapped geology (Figure 2) indicates the electrical properties imaged closely relate with the different hydrogeologic properties of different formations and members of the Edwards-Trinity carbonate rocks. The primary porosity heterogeneity is one component of the permeability signature, and quantified with the electrical resistivity data. This is most clearly observed is where the Kainer Formation (Edwards Group) has been juxtaposed through normal faulting adjacent to the upper members of the Glen Rose Formation (Trinity) in the southeast section of Camp Bullis. The differences in primary porosity between these two formations are substantial, and are clearly reflected in the HFDEM data. Other members within the Glen Rose also show substantial electrical variation, and relate to increased porosity and varied lithology associated with reefal depositional environment of the Lower Glen Rose along Cibolo Creek. 


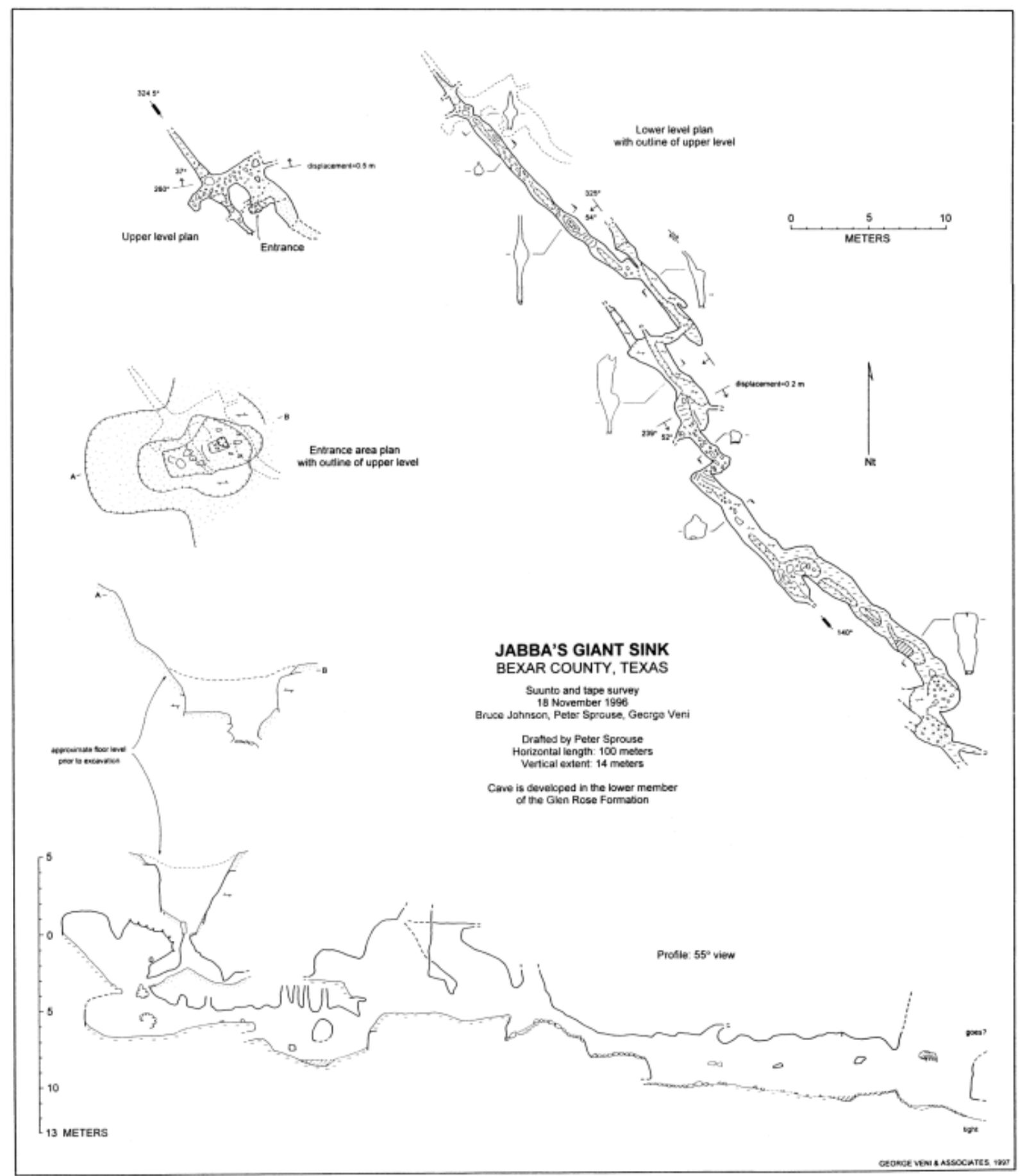

Figure 8. Cave map of Jabba's Giant Sink cave, located on the right bank (south) of Cibolo Creek. The cave extends below the creek bed and has been observed to rapidly recharge the aquifer through an active whirlpool during floods (Zara and Veni, 2010). 


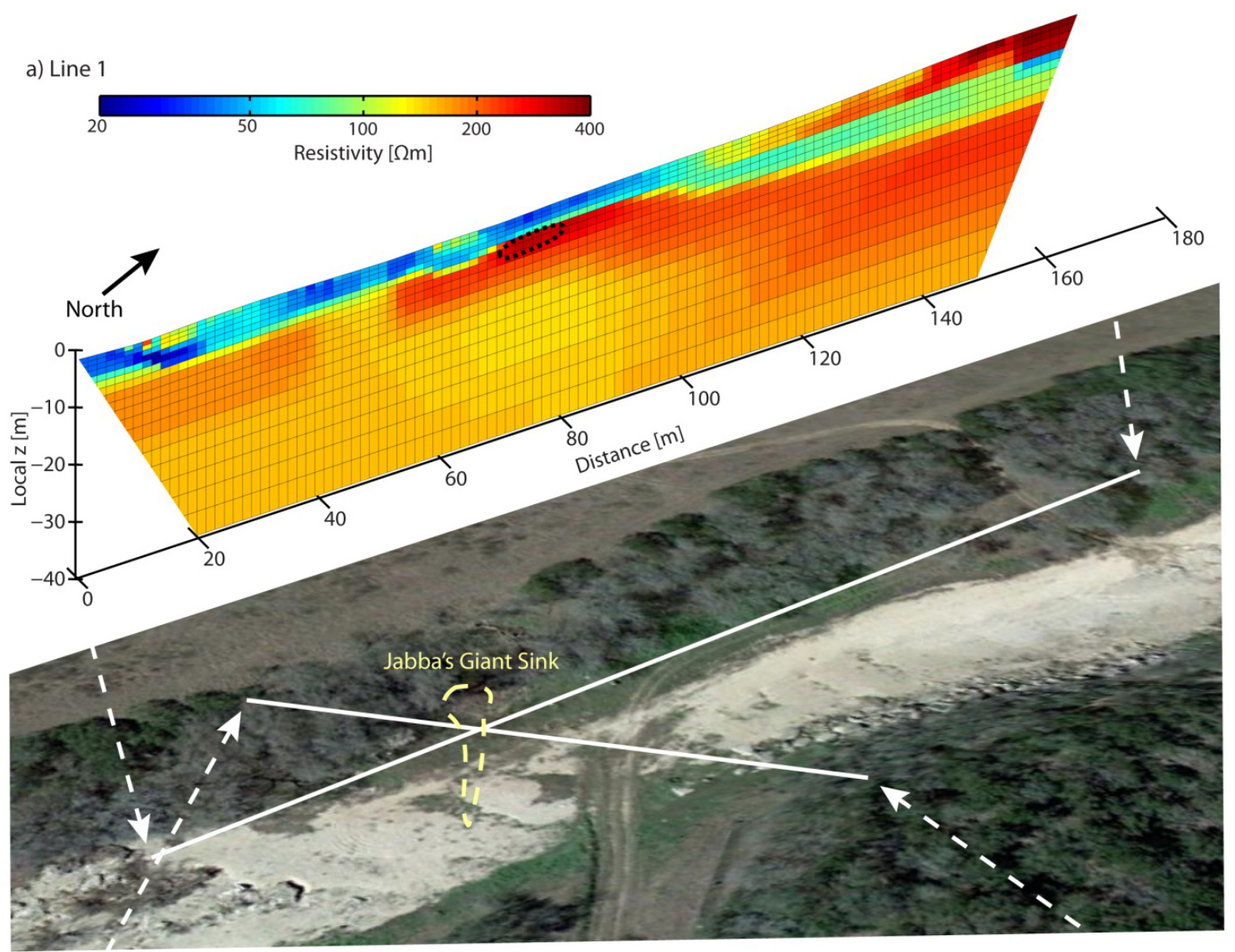

b) Line 2

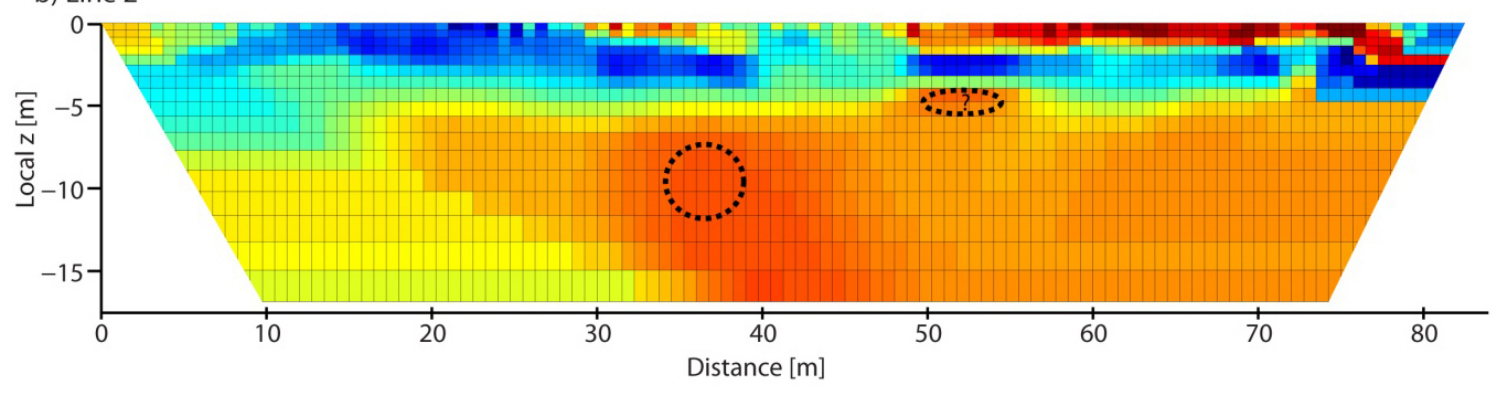

Figure 9. ER results at Jabba's Giant Sink (cave outline shown in orange). Both lines 1 and 2 resolve high ER features where the cave was expected to cross into the surveys ( $75 \mathrm{~m}$-line 1; $\sim 40 \mathrm{~m}$-line 2). Line 2 may have resolved a shallower cavity $(\sim 50 \mathrm{~m})$.

Secondary permeability is reflected in the faulting and subsequent karstification of the Edwards and Trinity aquifers in this region of central Texas, and is one of the major factors that make the Edwards Aquifer is such a prolific water source. Camp Bullis has been meticulously surveyed for karst features, possibly in greater detail than any other large, contiguous area in the U.S. This rich dataset (Zara, 2010) provides a unique opportunity to compare known, evaluated karst features with the regional electrical properties (Figures
3 and 4). Areas of high resistivity in the HFDEM data have a significant correlation with zones of high density karst features. This can be expected, since air-filled karstic voids have a significant effect on the electrical signature. This is shown on the local scale by the other two DC-ERI surveys conducted on Camp Bullis. They were conducted in areas of moderate to high resistivity in the HFDEM data, and show that voids do have a significant impact on the electrical properties in the study area. The likely resultant HFDEM data set likely 
reflects both increased primary porosity in the matrix rocks and enhanced secondary porosity in the faults, fractures, solutional voids, and karst conduit networks. This electrical reflection of the permeability structure of the Edwards-Trinity aquifer system of the HFDEM data could be a significant tool applied throughout the region to improve our understanding of the spatial heterogeneity of aquifer recharge.

\section{Conclusion}

Three different electrical geophysical studies performed at Camp Bullis were evaluated for their characterization of the permeability fabric of the Edwards and Trinity aquifers in central Texas. HFDEM data of the entire study area closely correlate with mapped geologic outcrops and spatial distribution of karst features. Localized DC-ERI investigations at two settings correspond to electrical signatures (high resistivity zones) of the HFDEM data, and show the applicability of potentially identifying karstic voids, or areas with more secondary karstification. The unique, extensive hydrogeologic data that exists for Camp Bullis can be expressed in the electrical signature of the subsurface, and quantified on a large scale by HFDEM datasets. Applying this methodology throughout the region to improve quantification of recharge could significantly increase the ability of regional groundwater models to simulate aquifer dynamics of the Edwards and Trinity aquifers and their interaction with each other.

\section{Acknowledgements}

Research presented in this paper is greatly indebted to the staff and management of the Environmental Office at Camp Bullis, particularly Lucas Cooksey and Chris Thibodeaux. Their support of ongoing, integrated scientific research in the region has been critical for all work performed at Camp Bullis. We thank the U.S. Department of Defense and the Edwards Aquifer Authority for funding the HFDEM surveys. We also thank the University of Texas at Austin Applied Karst Hydrogeology classes of 2011 and 2012, including Jack Sharp, for conducting the DC-ERI surveys at the sites along Cibolo Creek. Robin Gary of the Barton Springs Edwards Aquifer Conservation District provided GIS skills in processing much of the karst data and preparing maps. George Veni and Associates and Zara Environmental performed years of karst research at the site, providing the rich karst dataset used for analysis. We also thank those who gave thorough reviews of this manuscript: Allan Clark, Charles Blome, Ron Green, Robert Morris, Steve Johnson, and others who commented on the material.

\section{References}

Clark AC. 2003. Geologic Framework and hydrogeologic features of the Glen Rose Limestone, Camp Bullis Training Site, Bexar County, Texas. U. S. Geological Survey Water-Resources Investigation Report 03-4081.

Clark AR, Blome CD, Faith JR. 2009. Map showing geology and hydrostratigraphy of the Edwards Aquifer catchment area, northern Bexar County, south-central Texas. U. S. Geological Survey Open-file Report 2009-1008.

Day-Lewis FD, Singha K, Binley AM. 2005. Applying petrophysical models to radar travel time and electrical resistivity tomograms: Resolutiondependent limitations. J Geophys Res-Sol Ea. DOI 10.1029/2004jb003569.

Ferrill DA, Sims DW, Morris AP, Waiting DJ, Franklin N. 2003. Structural controls on the Edwards Aquifer/Trinity Aquifer interface in the Camp Bullis Quadrangle, Texas. Southwest Research Institute report prepared for the Edwards Aquifer Authority and U.S. Army Corps of Engineers.

Loke MH, Wilkinson PB, Chambers JE. 2010. Parallel computation of optimized arrays for 2-D electrical imaging surveys. Geophysical Journal International 183: 1302-1315.

Rucker DF. 2012. Enhanced resolution for long electrode ERT. Geophysical Journal International 191: 101-111.

Smith BD, Cain MJ, Clark AK, Moore DW, Faith JR, Hill PL. 2005. Helicopter electromagnetic and magnetic survey data and maps, northern Bexar County. U.S. Geological Survey Open-file report 2005-1158.

Stein WG, Ozuna GB. 1995. Geologic framework and hydrogeologic characteristics of the Edwards aquifer recharge zone, Bexar County, Texas. U.S. Geological Survey Water-Resources Investigations Report 95-4030.

Zara Environmental, Veni and Associates. 2010. Hydrogeological, biological, archeological, and paleontological karst investigations, Camp Bullis, Texas. Prepared for Natural and Cultural Resources Environmental Division, Fort Sam Houston, San Antonio, Texas.

Zara Environmental. 2011. Karst hydrogeology of Camp Bullis, Bexar and Comal Counties: A window into the Edwards-Trinity aquifer system. Prepared for Natural and Cultural Resources Environmental Division, Fort Sam Houston, San Antonio, Texas. 